\title{
German court blocks ban on animal tests
}

Munich. An appeals court in the state of Hessen has upheld a ruling by a local court that the state government infringed Germany's constitution last October when it tried to ban all experiments using animals from undergraduate courses at the University of Marburg (see Nature 365, 778; 1993).

The country's animal protection law says that animals may be used in teaching only if no adequate alternative exists. But the local court had decided earlier in the month that this law could not be used to restrict the freedom of teachers, as guaranteed by the constitution, to choose how to teach.

In an apparent protest at this decision and support of a long campaign by students against the use of animals in undergraduate teaching courses, animal rights activists stole 86 rabbits and 78 dwarf hamsters being used in experiments at the university in a raid on Christmas night.

The students' campaign has become focused on a single experiment on anaesthetized rats which still remains in the zoology curriculum, and which they say could be replaced by a film. It was the state government's attempt to ban this experiment that has now been rejected by the courts.

The decision has increased the polarization between opposing sides in the dispute. The Health and Research Society (Gesellschaft Gesundheit und Forschung), which protects the interests of research workers, has described it as a "victory for science" that gives biology teachers more freedom to decide how to conduct classes.

But Brigid Völlm of the Bundesverband SATIS, a national student pressure group concerned with the misuse of animals in teaching, describes the decision, which was made unusually rapidly, as a "catastrophe" for animal rights activists.

"It means that we will no longer be able to fight against animal experiments using the animal protection law," says Völlm. But she adds that her organization will continue to defend the rights of students not to work with animals, on the grounds that requiring students to do so infringes their own individual freedom.

The stolen animals have not yet been found. Gerald Heldmaier, a professor of zoology at Marburg who claims that the number of animals used in his course has been reduced to a bare minimum in response to public concern, describes the theft as "criminal".

Heldmaier says that the lives of the animals have been put in danger. But Völlm denies this, saying that a veterinary surgeon was present during the raid, and that the animals are being well cared for in private homes.

\section{Attacks prompt demand for new law}

London. Britain's Home Secretary, Michael Howard, has been asked to introduce tougher legislation to curb attacks by animal rights activists on individuals and institutions involved in medical research.

The request has come from Sir Colin Berry, professor of morbid anatomy and dean elect of the London Hospital Medical College, and president of the Research Defence Society (RDS), a body set up to defend the use of animals in research.

It follows a recent upsurge in attacks by animal rights groups. These include letter bombs sent to the home of a prominent physiology researcher in Oxford, to employees of Glaxo's laboratories in Stevenage and to a biological organization in London.

RDS believes that, with 34 incidents in the past three months, the attacks herald a new protest campaign. "In terms of number of violent attacks, this is the most worrying escalation that we have since the animal rights extremist started operating in the mid1970 s," says Mark Matfield, the executive director of the society.

\section{Anti-HIV claims were 'grossly distorted'}

London. Claims by Britain's Sunday Times that the human immunodeficiency virus (HIV) does not lead to AIDS, and that the AIDS epidemic in African countries has been exaggerated, have been strongly denied by a doctor whose work has been used as a central component in the newspaper's justification of its case.

Angelo d'Agostino, chairman of a Nairobi hospice, has said that he wants to "categorically distance" himself from the "gross distortions" in a Sunday Times article about his work, published last August.

In that article, Neville Hodgkinson, the newspaper's science correspondent, reported that HIV-infected orphan children in d'Agostino's hospice were not in the process of developing AIDS, and that this experience "flies in the face of the conventional theories about the history of Aids in Africa".
D'Agostino, in a statement on 6 January to The Independent on Sunday which has itself recently published features highlighting the AIDS epidemic in African countries - says that Hodgkinson did not indicate his own views during their three-hour meeting.

He said that he "cannot help but wonder about the motivation for such terrible journalism and, more so, decry the terrible effects on the unsuspecting public who are given a false sense of security and run the very real risk of contracting an incurable disease as a consequence".

D'Agostino asked the Sunday Times to correct Hodgkinson's article soon after it appeared, but received no acknowledgement. He issued a press release to draw attention to the erroneous report, and wrote again to Hodgkinson. No correction has been published. Maxine Clarke

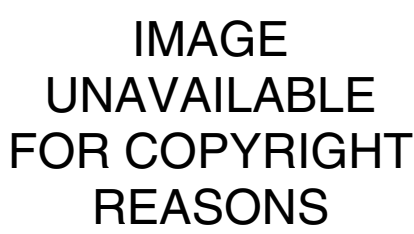

Rough justice: can tighter legislation stop animal rights attacks such as this?

No group has claimed responsibility for the latest round of attacks. Some newspaper reports, however, have suggested that they may have been carried out by a previously unknown group calling itself the Justice Department.

RDS members point out that the government has already agreed to clamp down on the activities of hunt saboteurs by including a new crime of "aggravated trespass" in its criminal justice bill. This bill was presented to parliament shortly before Christmas and will soon be debated in the House of Commons.

The RDS proposal has been backed by various moderate groups concerned with animal welfare. "People are breaking the law, and that is not the way to reduce the use of animals in research" says Julia Fentem, scientific liaison officer of the Fund for the Replacement of Animals in Medical Experimentation.

Some medical scientists, however, fear that tough new legislation might further polarize the debate. They point out that existing legislation covers violent crimes committed by protesters, and are concerned that an over-reaction to recent events might provoke a backlash by hardening the attitude of animal rights groups.

"Long prison sentences may well give researchers some protection against the more fanatical protesters, but I do not think that tougher sentences will in themselves be any sort of deterrent," says Sir Dai Rees, the secretary of the Medical Research Council.

David Dickson 